\title{
Rencana Umum Kapal Katamaran Tipe Glass Bottom Untuk Sarana Pariwisata di Kepulauan Derawan, Kalimantan Timur
}

\section{The General Arragement Catamarans Ship of Glass Bottom Type for Vacation Tools at Derawan Island of East Kalimantan}

\author{
Alamsyah ${ }^{1, *}$, Bebeto Fandi Birana ${ }^{1}$ \\ ${ }^{1}$ Teknik Perkapalan, Jurusan Sains Teknologi Pangan dan Kemaritiman, Institut Teknologi Kalimantan, 76127, Indonesia
}

\author{
* Penulis korespondensi : alamsyah@itk.ac.id \\ Tel.: +62-85-242-800-578; fax::- \\ Diterima: 23 Juli 2019; Direvisi: 20 Oktober 2019; Disetujui: 22 Oktober 2019. \\ DOI: 10.25299/saintis.2019.vol19(02).3455

\section{Abstrak}

Banyak wisatawan yang berkunjung di Kepulauan Derawan, sebagian besar melakukan kegiatan penyelaman. Namun, jumlah kunjungan ini tidak diimbangi dengan sarana transportasi laut yang layak teknis dan layak laut. Tujuan penelitian ini yakni menemukan data-data berupa ukuran utama, rencana garis, dan rencana umum desain kapal katamaran. Metodelogi yang digunakan dalam penelitian ini yakni dengan Trend Curve Approach dan optimasi desain dengan software Maxurf Modeler Advanced. Hasil penelitian yang didapat adalah ukuran utama kapal dengan rincian sebagai berikut; $L=21 \mathrm{~m}, B=10 \mathrm{~m}, B_{1}=2.4 \mathrm{~m}, H=5 \mathrm{~m}, T=2 \mathrm{~m}, V_{s}=10$ knot, $C b=0.33$, Daya Mesin $=86$ HP (Untuk 1 Mesin), Jumlah Penumpang dan Kru = 87 Orang.

Kata Kunci: kapal, pariwisata, glass bottom, kepulauan derawan

\begin{abstract}
Many tourists visiting the Derawan Islands, most do diving. However, the number of visits is not balanced with the means of sea transportation that is technically feasible and seaworthy. The purpose of this study was to find data in the form of main dimention, lines plan, and general arragement for the design of glass bottom catamaran vessels. The methodology used in this study is the Trend Curve Approach and design optimization with Maxurf Modeler Advanced software. The results of the research obtained are the main size of the ship obtained as follows; $L=21 \mathrm{~m}, B=10 \mathrm{~m}, B 1=2.4 \mathrm{~m}, H=5 \mathrm{~m}, T=2 \mathrm{~m}, V_{s}=10$ knots, $C b=0.33$, Engine Power $=86 \mathrm{HP}$ (For 1 Machine), Number of Passengers and Crew $=87$ Persons.
\end{abstract}

Keywords: vessels, vacation, glass bottom, derawan island

\section{PENDAHULUAN}

Pemerintah Indonesia sedang berupaya mengembangkan sektor kemaritiman sebagai ujung tombak perekonomian. Sektor yang bisa dikembangkan adalah pariwisata bahari. Tujuan sektor ini dipilih yakni untuk pemasukan negara dan sebagai ajang memperkenalkan keindahan alam laut Indonesia.

Indonesia merupakan salah satu negara kepulauan terbesar dengan memiliki garis pantai $81.000 \mathrm{~km}$ dan mempunyai total luas terumbu karang sekitar $60.000 \mathrm{~km}^{2}$ yang terhampar dari ujung barat sampai ujung timur wilayah laut Indonesia. Indonesia merupakan rumah dari $1 / 8$ dari jenis terumbu karang yang ada di dunia. Dari data dan fakta, laut Indonesia dapat menjadi nilai jual tersendiri untuk dijadikan iming-iming bagi wisatawan lokal maupun asing agar berwisata di wilayah laut Indonesia (Wikipedia.org,2016).

Salah satu tempat yang bisa dikunjungi untuk pariwisata bahari adalah Kepulauan Derawan yang berada di Kabupaten Berau, Provonsi Kalimantan
Timur. Berikut adalah lokasi kepulauan Derawan dilihat dari google maps, Terlihat pada Gambar 1.

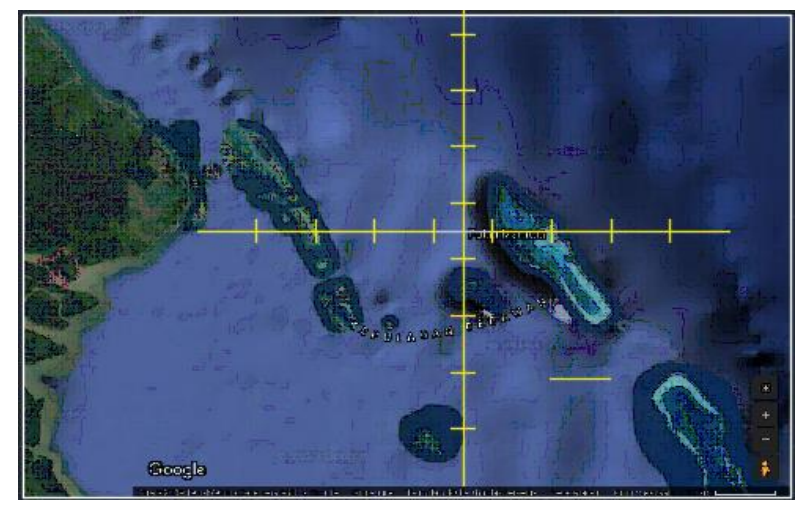

Gambar 1. Kepulauan Derawan

Kepulauan Derawan sendiri menjadi sorotan oleh media-media di tahun-tahun terakhir ini karena potensi pariwisata baharinya yang sedang naik daun seperti Kepulauan Raja Ampat di Provinsi Papua Barat. Reputasinya bahkan sampai ke luar negeri, dimana ada turis mancanegara yang berlibur 
ke Kepulauan Derawan dan menghabiskan waktu 3 hari sampai 1 minggu [2].

Jumlah pengunjung Kepulauan Derawan sendiri terbilang luar biasa, berdasarkan data dari Wakil Bupati Berau Agus Tantomo, total keseluruhan kunjungan mencapai 15 juta orang, dimana 3 juta orang melakukan kegiatan menyelam. Dan menurut data dari Badan Pusat Statistik Kabupaten Berau, ada peningkatan jumlah pengunjung hingga lebih dari 100 ribu di tahun 2015, data lainnya juga diperoleh dari Dinas Kebudayaan dan Pariwisata Berau, pada tahun 2016 kunjungan turis di Kabupaten Berau sendiri mencapai 321557 wisatawan [5]. Namun, jumlah kunjungan ini tidak diimbangi dengan fasilitas berupa transportasi laut, yang tersedia sebagian besar merupakan perahu kayu kecil yang memiliki masalah-masalah berupa kapasitas muatan yang sedikit, tidak ada fasilitas berupa kursi penumpang, alat keselamatan, ataupun asuransi untuk penumpang dan kru kapal. Karena beberapa hal di atas, maka penulis berencana untuk membuat "Desain Kapal Glass Bottom Catamaran Sebagai Sarana Wisata Kepulauan Derawan, Kabupaten Berau, Kalimantan Timur".

\section{METODOLOGI}

Metodologi yang digunakan yakni metode trend curve approach dan dioptimasi menggunakan software maxurf (ship basic data/parametric ship design). Data awal diambil dari beberapa kapal pembanding, kemudian diregresi dengan menggunakan ms. excel untuk mendapatkan ukuran utama. Proses penyusunan set ukuran utama kapal dilakukan melalui langkah-langkah sebagai berikut:

\section{Penentuan Ukuran Utama Kapal}

Mencari ukuran utama kapal dengan metode regresi linier. Dalam penentuan ukuran utama awal, data yang diperlukan adalah displasemen dan kapal pembanding dengan rentang displasemen $\pm 10 \%$ dari displasemen kapal. Menurut artikel Terho Halme, berat muatan adalah 20\% dari displasemen kapal. Karena kapal yang didesain mengangkut muatan penumpang, maka berat total penumpang dan barang bawaan adalah $20 \%$ dari displasemen kapal. Serta persamaan-persamaan yang berlaku, didapat dari Intac Stability code Chapter 3 - Part A. Sebagai berikut [3] :

$$
\begin{aligned}
\Delta= & 20 \% \text { Berat Muatan }+80 \% \text { Komponen } L W T \\
& \text { dan } D W T
\end{aligned}
$$

Karena 80\% komponen lainnya belum ditentukan, maka persamaan displasemen dapat ditulis;

$$
\Delta=5 \times 20 \% \text { Berat Muatan }
$$

Dimana,

$\Delta=$ Displasemen kapal

$L W T=$ Light Weight Ton
DWT $=$ Dead Weight Ton

Berat muatan = berat penumpang dan barang bawaan

Sehingga didapatkan berat muatan :

$80 \times(75+10)=6800 \mathrm{~kg}$

Dan displasemen kapal :

$5 \times 6800 \mathrm{~kg}=34000 \mathrm{~kg}$

Selanjutnya, ukuran utama awal kapal yang didesain dapat dicari melalui regresi linier dari kapal-kapal pembanding, pada Tabel 1. Ukuran utama dari hasil regresi yang diperoleh dibkoreksi dengan rasio-rasio ukuran utama kapal yang

\begin{tabular}{|c|c|c|c|c|c|c|}
\hline $\begin{array}{l}\text { Nama } \\
\text { Kapal }\end{array}$ & $\begin{array}{l}\mathbf{S} \\
(\mathbf{m} / \mathbf{s})\end{array}$ & $\begin{array}{l}4 \\
\text { (ton) }\end{array}$ & $\begin{array}{l}\text { Lpp } \\
(\mathbf{m})\end{array}$ & $\begin{array}{l}B \\
(\mathbf{m})\end{array}$ & $\begin{array}{l}\boldsymbol{H} \\
(\mathbf{m})\end{array}$ & $\begin{array}{l}T \\
(\mathbf{m})\end{array}$ \\
\hline sd nutbourne & 4,8 & 10,0 & 18,0 & 7,0 & 4,6 & 1,8 \\
\hline kostervind & 3,2 & 11,0 & 19,0 & 8,0 & 4,5 & 1,5 \\
\hline wega ii & 3,5 & 16,0 & 20,0 & 6,0 & 4,7 & 1,5 \\
\hline fastnet rock & 3,3 & 13,0 & 21,0 & 7,0 & 4,6 & 1,4 \\
\hline rygerprins & 3,4 & 12,0 & 21,0 & 8,0 & 5,0 & 2,0 \\
\hline alexander & 3,4 & 33,0 & 22,0 & 7,0 & 4,8 & 2,0 \\
\hline $\begin{array}{l}\text { lovund } \\
\text { express }\end{array}$ & 3,4 & 11,0 & 22,0 & 8,0 & 4,3 & 1,6 \\
\hline flota lass & 3,4 & 10,0 & 22,0 & 8,0 & 4,3 & 1,7 \\
\hline $\begin{array}{l}\text { aurora } \\
\text { explorer }\end{array}$ & 3,4 & 20,0 & 23,0 & 9,0 & 5,4 & 2,0 \\
\hline issehoved & 3,5 & 38,0 & 23,0 & 8,0 & 5,0 & 2,0 \\
\hline yubileyny & 3,3 & 14,0 & 23,0 & 6,0 & 4,3 & 1,6 \\
\hline rygercruise & 3,3 & 16,0 & 23,0 & 8,0 & 5,0 & 2,0 \\
\hline batamfast6 & 3,4 & 14,0 & 23,0 & 5,0 & 4,2 & 1,7 \\
\hline $\begin{array}{l}\text { inzhener } \\
\text { popovich }\end{array}$ & 3,4 & 14,0 & 23,0 & 6,0 & 4,4 & 1,7 \\
\hline almaz & 3,4 & 14,0 & 21,0 & 6,0 & 4,0 & 1,8 \\
\hline penguin ubin & 3,5 & 15,0 & 23,0 & 7,0 & 4,0 & 1,4 \\
\hline $\begin{array}{l}\text { punta europa } \\
\text { segundo }\end{array}$ & 3,4 & 15,0 & 25,0 & 8,0 & 3,9 & 1,3 \\
\hline rygertroll & 3,5 & 15,0 & 25,0 & 8,0 & 4,5 & 1,4 \\
\hline flordglimt & 3,4 & 19,0 & 25,0 & 8,0 & 5,2 & 2,0 \\
\hline nordwind & 3,2 & 18,0 & 25,0 & 7,0 & 4,0 & 1,4 \\
\hline brage & 3,4 & 19,0 & 25,0 & 8,0 & 4,2 & 1,6 \\
\hline $\begin{array}{l}\text { trondherimsf } \\
\text { jord ii }\end{array}$ & 3,4 & 19,0 & 25,0 & 8,0 & 4,2 & 1,5 \\
\hline umoe rapid & 3,5 & 15,0 & 25,0 & 10,0 & 5,4 & 2,0 \\
\hline
\end{tabular}
mengacu pada riset $M$. Insel dan A. F Molland [4].

Tabel 1. Data Kapal Pembanding

(Sea Speed Design dan Incat Crowther, 2019)

Dengan $\Delta$ sebagai nilai sumbu $X$, dan variabel-variabel seperti $L p p, B, H$, dan $T$ sebagai sumbu Y akan didapatkan nilai-nilai sumbu Y dari grafik regresi linier. Regresi berupa kurva linear untuk setiap variabel ukuran utama yang dilengkapi dengan persamaan garis seperti terlihat pada Gambar 2. 


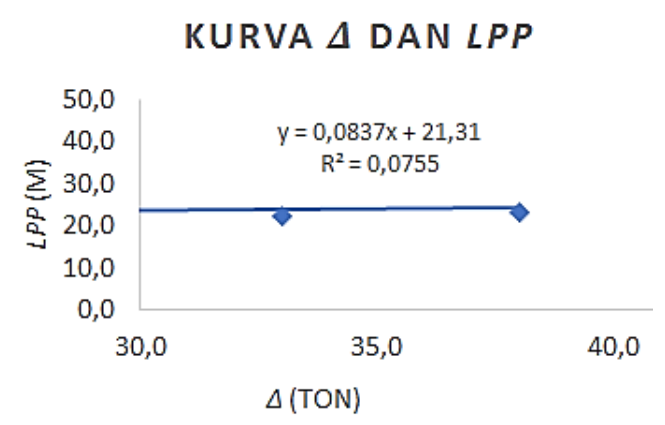

Gambar 2. Kurva Regresi Linier

Kurva regresi variabel $\Delta$ dan variabel lainnya (Lpp, $B, T$, dan $H$ ) akan dijadikan standar penentuan ukuran utama sementara kapal rancangan dengan nilai minimum $R^{2}=0,4$ yang ditetapkan di awal rancangan. Setelah mendapatkan variabel-variabel ukuran utama kemudian dilakukan optimasi dengan bantuan software maxurf. Sistem kerja maxurf yakni menggunakan parametric ship design yang berorentasi pada ship basic data. Software tersebut memudahkan perancang dalam mendesain kapal karena terdapat banyak sampel kapal yang bisa dijadikan referensi. Dengan memasukkan ukuran utama sementara kapal rancangan pada maxurf, secara otomatis akan didapatkan variabel-variabel ukuran utama kapal lainnya.

\section{Penentuan Koefisien Bentuk Kapal}

Nilai koefisien bentuk kapal yang pertama ditentukan yakni koefisien blok $\left(C_{B}\right)$. Perhitungan ditentukan dengan menggunakan formula sbb :

$$
C_{B}=\nabla /(B 1 \times L \times T)
$$

Dimana;

$\nabla=$ Volume karena

$B 1$ = Lebar tiap lambung

$L=$ panjang garis air kapal

$T=$ sarat kapal

Selanjutnya koefisien lainnya seperti koefisien prismatik $(C p)$, koefisien waterplane $(C w p)$, dan koefisien midship $(\mathrm{Cm})$ ditentukan dengan menggunakan software maxurf. Data ukuran utama dan koefisien bentuk kapal digunakan untuk penggambaran rencana garis (lines plane) dan rencana umum kapal rancangan (General arragement).

\section{Penentuan Hambatan Kapal}

Untuk perhitungan hambatan kapal lambung katamaran, dapat menggunakan metode dari $M$. Insel dan A. F Molland [4]. Persamaan yang digunakan untuk menentukan besarnya hambatan mengacu pada Persamaan berikut;

$R t=0.5 \times \rho \times 2 \times W S A \times V^{2} \times C t o t$

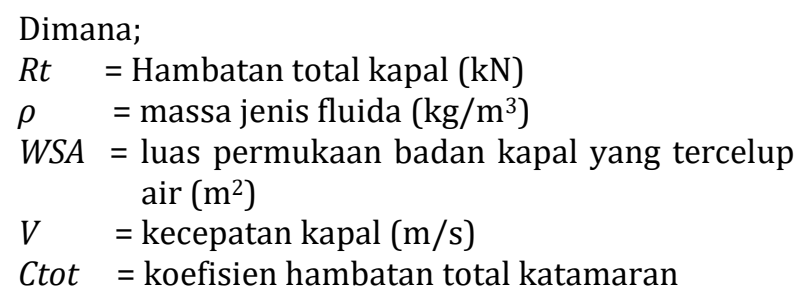

\section{Penentuan Kebutuhan Daya Mesin Kapal}

Setelah besarnya hambatan diketahui, tahap selanjutnya yaitu menentukan besarnya daya yang dibutuhkan [6]. Berikut tahap-tahap yang dilakukan;

1. Perhitungan $E H P$ $E H P=R T \times V$

2. Perhitungan $D H P$

$D H P=E H P / \eta \mathrm{n}$

3. Perhitungan $B H P$ $B H P=D H P+(X \% D H P)$

Dimana;

$E H P=$ Effective Hourse Power

DHP $=$ Delivery Horse Power

$B H P=$ Break Hourse Power

$\eta D=$ Quasi Propulsive Coefficient $\eta H \cdot \eta \mathrm{O} \cdot \eta r$

$\eta H=$ Hull Efficiency

$\eta r=$ Rotative Efficiency

$\eta O=$ Open Water Test Propeller Efficiency

$X \%=$ koreksi daerah pelayaran wilayah Asia Timur $(15 \%$ - 20\% DHP)

Nilai $B H P$ menjadi dasar penentuan daya atau pemilihan mesin kapal rancangan. Sedangkan kebutuhan daya genset diasumsikan $25 \%$ dari daya mesin induk.

\section{Pemodelan Kapal Rancangan Pada Software Maxurf}

Tahap awal yang dilakukan adalah pembuatan surface kapal rancangan. Dalam pembuatannya, dibutuhkan data ukuran utama dan koefisien bentuk kapal. Tahapan secara umum yang dilakukan pada pemodelan yakni :

1. Pembuatan Surface kapal rancangan

2. Pengaturan Unit, Size Surface, Design Grid dan Frame of References

3. Pengaturan Control Point

4. Export Lines Plan dari software Maxsurf Modeler-Cad

Pemodelan pada maxurf akan menampilkan bentuk 3 dimensi kapal rancangan, dan juga bentuk 2 dimensi meliputi profile view, plan view, dan body plan view. Pemodelan maxurf seperti terlihat pada Gambar 3 sebagai berikut: 


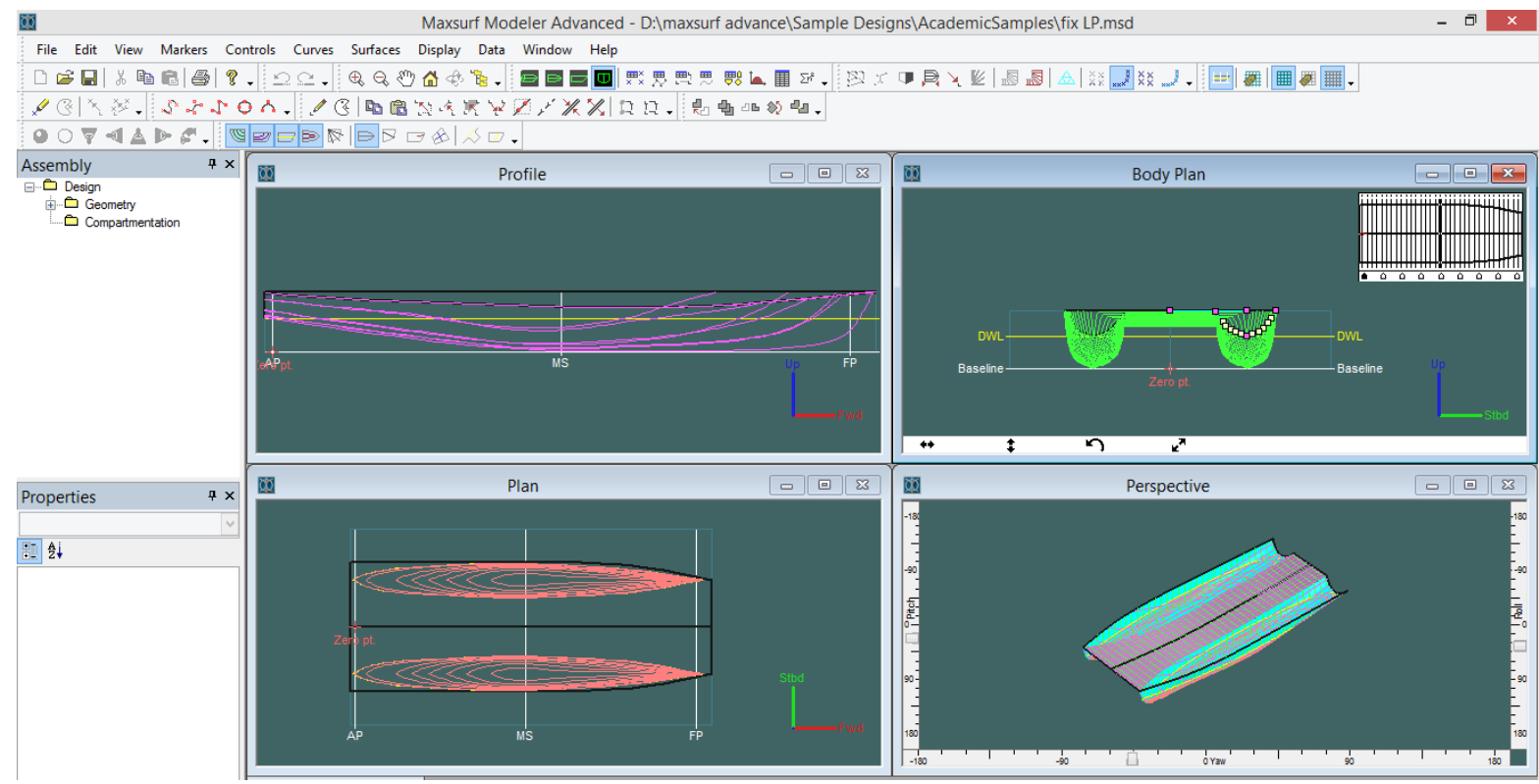

Gambar 3. Pemodelan $n$

\section{HASIL DAN DISKUSI}

\section{Ukuran Utama Kapal Sementara}

Variabel-variabel ukuran utama kapal seperti Lpp pada Gambar 2, serta $T$, $B$, dan $H$ yang didapatkan dengan menggunakan persamaan kurva regeresi linier seperti terlihat pada Gambar 4, 5, dan 6 sebagai berikut:

KURVA $\triangle$ DAN $T$

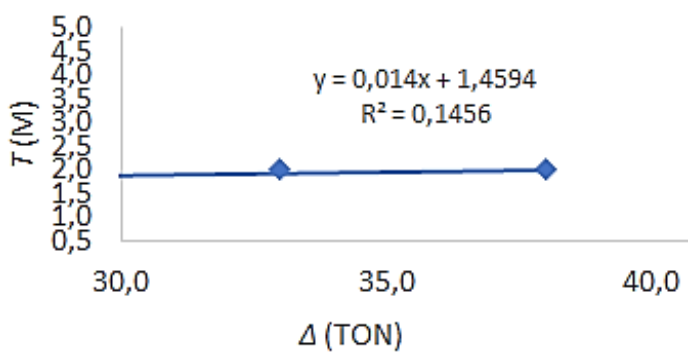

Gambar 4. Kurva Regresi Variabel $\Delta$ dan $\mathrm{T}$

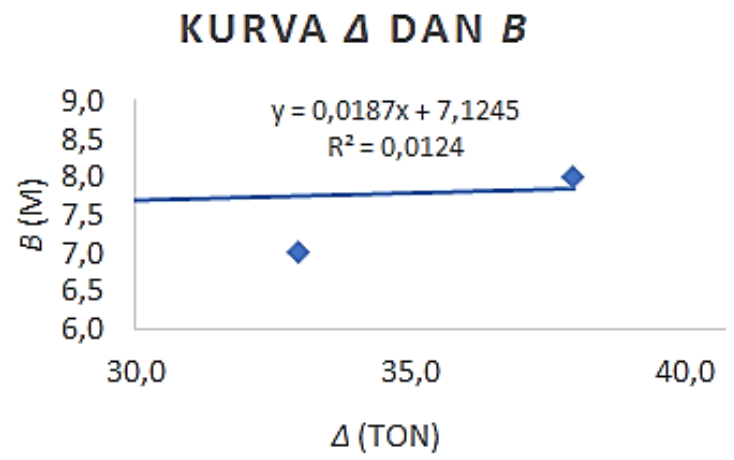

Gambar 5. Kurva Regresi Variabel $\Delta$ dan $\mathrm{T}$

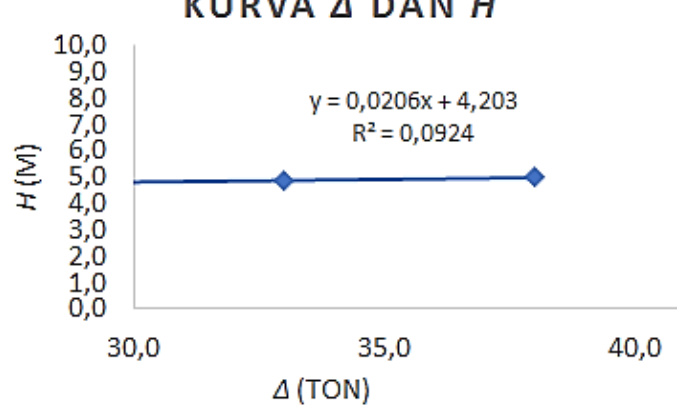

Gambar 6. Kurva Regresi Variabel $\Delta$ dan $\mathrm{H}$

Gambar 2, 4, 5, dan 6 merupakan kurva yang memiliki persamaan regresi linier untuk menentukan variabel ukuran utama. Persamaan regresi linier untuk masing-masing variabel sebagai berikut:

$Y=0,014 x+1,4594$

(untuk nilai T)

$Y=0,0187 x+7,1245$

(untuk nilai $B$ )

$Y=0,0206 x+4,203$

(untuk nilai $H$ )

$\mathrm{Y}=0,0837 \mathrm{x}+21,31$

(untuk nilai $L p p$ )

sehingga didapatkan ukuran utama sementara yakni $T=1,9354 \quad \mathrm{~m}, B=7,7603 \mathrm{~m}, H=4,9034 \mathrm{~m}$, dan Lpp $=24,155 \mathrm{~m}$ dengan nilai $R^{2}$ di bawah 0,4 . Hasil ukuran utama dengan nilai $R^{2}$ tersebut tidak memungkinkan untuk dijadikan ukuran utama kapal karena nilai $R^{2}$ tidak lebih besar atau sama dengan $0,4\left(R^{2} \geq 0,4\right)$. Menurut teori regresi linier nilai $R^{2}$ yang semakin mendekati nilai 1 akan 
semakin bagus, sehingga dilakukan optimasi menggunakan software maxurf dengan parameter rasio ukuran utama kapal sebagai berikut [4] :
1) $6<L / B 1<11$
2) $6<L / H<11$
3) $0,7<B / H<4,1$
4) $0,2<S / L<0,5$
5) $1<S / B<4$
6) $1<B / T<3$
7) $0,15<B 1 / B<0,3$
8) $0,36<C_{B}<0,59$

Parameter rasio ukuran utama di atas dijadikan patokan dalam menentukan ukuran utama defenitif kapal rancangan dengan bantuan software maxurf. Hasil koreksi ukuran utama kapal rancangan seperti terlihat pada Tabel 2 sebagai berikut :

Tabel 2. Hasil Koreksi Ukuran Utama Kapal Rancangan

\begin{tabular}{llll}
\hline Rasio & Nilai & Rentang Rasio & Kondisi \\
\hline$L / B 1$ & 9,800 & $6<L / B 1<11$ & Accept.ed \\
$L / H$ & 9,800 & $6<L / H<11$ & Accepted \\
$B / H$ & 3,650 & $0,7<B / H<4,1$ & Accepted \\
$S / L$ & 0,270 & $0,2<S / L<0,5$ & Accepted \\
$S / B 1$ & 2,650 & $1<S / B<4$ & Accepted \\
$B 1 / T$ & 1,818 & $1<B / T<3$ & Accepted \\
$B 1 / B$ & 0,274 & $0,15<B 1 / B<0,3$ & Accepted \\
$C B$ & 0,398 & $0,36<C B<0,59$ & Accepted \\
\hline \multicolumn{7}{l}{ Hasil Olahan, 2019) }
\end{tabular}

Perbandingan ukuran utama kapal rancangan sebelum dan setelah dikoreksi seperti terlihat pada Tabel 3. Sebagai berikut:

Tabel 3. Perbandingan Ukuran Utama Kapal

\begin{tabular}{lllll}
\hline \multicolumn{2}{l}{$\begin{array}{l}\text { Ukuran Utama Sebelum } \\
\text { koreksi }\end{array}$} & & \multicolumn{2}{c}{ Setelah dikoreksi } \\
\hline Lpp & 24,2 & $\mathrm{~m}$ & 21 & $\mathrm{~m}$ \\
$\boldsymbol{B}$ & 7,8 & $\mathrm{~m}$ & 10 & $\mathrm{~m}$ \\
$\boldsymbol{B} 1$ & & $\mathrm{~m}$ & 2,4 & $\mathrm{~m}$ \\
$\boldsymbol{H}$ & 4,9 & $\mathrm{~m}$ & 5 & $\mathrm{~m}$ \\
$\boldsymbol{T}$ & 1,9 & $\mathrm{~m}$ & 2 & $\mathrm{~m}$ \\
$\boldsymbol{V} \boldsymbol{S}$ (lebar antar & & $\mathrm{Knot}$ & 10 & $\mathrm{Knot}$ \\
lambung) & 7,8 & $\mathrm{~m}$ & 5,2 & $\mathrm{~m}$ \\
\hline \hline (Hasil Olahan, 2019) & & & &
\end{tabular}

Proses optimasi didasari persyaratan metode perhitungan yang dipakai, serta persyaratanpersyaratan yang dikeluarkan oleh badan regulasi nasional maupun internasional seperti BKI, IMO, SOLAS, dan lainnya.
Penelitian ini terdapat beberapa batasan antara lain : batasan rasio ukuran utama kapal, batasan terkait berat kapal dan muatan terhadap displasemen kapal (Archimedes rule)

\section{Volume Kapal}

Displasemen adalah berat air yang dipindahkan oleh badan kapal yang tercelup dalam air, atau volume displasemen dikalikan dengan massa jenis air. Untuk menghitung displasemen kapal digunakan formula sebagai berikut [8] :

$$
\Delta=\nabla_{t} \times \rho_{\text {air }}
$$

dimana:

$$
\begin{array}{lll}
\Delta & =\text { displasemen kapal } & \text { (ton) } \\
\rho_{\text {air }} & =\text { massa jenis air tawar } & \left(1,000 \mathrm{~kg} / \mathrm{m}^{3}\right) \\
\nabla_{t} & =\text { Volume kapal } \mathrm{m}^{3} & \left(\mathrm{~m}^{3}\right)
\end{array}
$$

sehingga volume kapal,

$$
\nabla_{t}=\frac{34 \mathrm{ton}}{1,025 \mathrm{~kg} / \mathrm{m}^{3}}=33,171 \mathrm{~m}^{3}
$$

Setelah mendapatkan volume kapal kemudian dilakukan perhitungan koefisien bentuk kapal meliputi koefisien blok $(\mathrm{Cb})$, koefisien midship $(\mathrm{Cm})$, koefisien waterline $(C w)$ dan koefisien prismatik $(C p)$. Untuk mendapatkan nilai $C b$ kapal digunakan formula sebagai berikut :

$$
C b=\frac{\nabla t}{B_{1} x L x T}
$$

Sehingga $C b$ kapal,

$$
\begin{aligned}
& C b=\frac{33,171 \mathrm{~m}^{3}}{2,4 m \times 21 \mathrm{~m} \times 2 \mathrm{~m}} \\
& C b=0.165 \text { dikali } 2=0,33
\end{aligned}
$$

Untuk nilai $\mathrm{Cm}$, Cw, dan Cp didapatkan dengan metode ship basic data/parametric ship design yang pada maxurf dengan hanya memasukkan nilai $\mathrm{Cb}$ dan ukuran utama kapal kemudian oleh software maxurf secara otomatis memberikan nilai koefisien lain yang dibutuhkan. Sehingga didapatkan nilai $\mathrm{Cm}$ $=0,362, C p=0,539$, dan $C w=0,722$

\section{Perhitungan Hambatan Kapal}

Untuk perhitungan hambatan kapal katamaran dapat menggunakan metode dari $M$. Insel \& A. F Molland [4]. Kapal katamaran diasumsikan seperti kapal demihull yang ditambahkan dengan harga interferensi yang diakibatkan oleh lambung yang berjarak $s$ dari center line-nya. Nilai hambatan total dikalikan 2 karena luas permukaan bidang basah (Wetted Surface Area) terdapat ditiap lambung kapal. Persamaan yang digunakan untuk mendapatkan besarnya hambatan total mengacu pada Persamaan 4. Nilai WSA bisa didapatkan dengan menggunakan persamaan berikut [9] : 
$S=\frac{\nabla}{B 1}\left[\frac{1.7}{C b-0.2(C b-0.65)}+\frac{B 1}{T}\right]$

Dimana;

$S \quad=$ Luas bidang basah $\left(\mathrm{m}^{2}\right)$

$\rho \quad=$ massa jenis fluida $\left(\mathrm{kg} / \mathrm{m}^{3}\right)$

B1 = lebar tiap lambung demihull $(\mathrm{m})$

$T \quad=$ sarat kapal $(\mathrm{m})$

$\nabla \quad=$ Volume $\left(\mathrm{m}^{3}\right)$

sehingga didapatkan nilai $S=34,49 \mathrm{~m}^{2}$ per lambungnya. Untuk nilai $S$ total lambung akan dikalikan 2, sehingga didapatkan nilai $S=68,98 \mathrm{~m}^{2}$. Setelah mendapatkan nilai $S(W S A)$, kemudian kita dihitung nilai koefisien hambatan total kapal $\left(C_{t o t}\right)$. Nilai koefisien hambatan total kapal ditentukan dengan persamaan sbb :

$C_{\text {Tot }}=(1+\beta k) \cdot C f+\tau . C w$

(16)

Dimana ;

$C f=$ Koefisien hambatan gesek

$\mathrm{Cw}=$ Koefisien gelombang

$\tau=$ Faktor interferensi hambatan gelombang

$(1+\beta k)=$ Faktor interferensi hambatan gesek

Dari tahapan di atas, didapatkan nilai $C_{\text {tot }}=$ 0,008 . Dengan ditemukannya nilai $C_{\text {tot }}$ maka Hambatan total $\left(R_{T}\right)$ dapat dihitung dengan menggunakan persamaan (4). Nilai dari $R_{T}=$ 7621,55 Newton atau $7,26 \mathrm{kN}$.

\section{Perhitungan daya dan Pemilihan Mesin Kapal}

Setelah besarnya hambatan diketahui, tahap selanjutnya yaitu menentukan besarnya daya yang dibutuhkan [6]. Berikut adalah tahapan dan persamaan yang digunakan dalam menentukan daya. Pertama menentukan nilai EHP dengan menggunakan Persamaan 5. Sehingga didapatkan nilai $E H P=37,35 \mathrm{~kW}$. Kedua menetukan nilai $D H P$ dengan menggunakan Persamaan 6. Nilai DHP didapatkan yakni $69,27 \mathrm{~kW}$. Tahap selanjutnya menentukan nilai BHP dengan menggunakan Persamaan 7, sehingga didapatkan nilai $B H P=$ 79,663 kW. Nilai BHP ini kemudian dikonversi dalam bentuk satuan $\mathrm{Hp}$ (Hourse Power), alhasil didapatkan nilai $B H P=108,312 \mathrm{Hp}$. Nilai $B H P$ ini menjadi patokan dalam memilih tenaga mesin kapal yang sesuai.

Berdasarkan perhitungan di atas, maka daya minimal yang dibutuhkan oleh kapal adalah 108,312 Hp. Sedangkan kebutuhan daya genset diasumsikan $25 \%$ dari daya mesin induk yakni 27,078 Hp. Direncanakan mesin dan genset kapal terdiri masing-masing 2 pcs yang diletakkan di masingmasing demihull yang menjadi dasar pertimbangan dalam memilih mesin pada brosur atau engine catalog. Dalam hal ini, genset dan mesin induk yang digunakan yakni merek Caterpillar [1] seperti terlihat pada Tabel 4 dan 5 sebagai berikut.

Tabel 4. Spesifikasi Mesin induk

\begin{tabular}{lll}
\hline Variabel & & Harga dan Satuan \\
\hline Model & $:$ & $3054 \mathrm{~B}$ \\
Daya & $:$ & $64 \mathrm{~kW}$ \\
& $:$ & $86 \mathrm{HP}$ \\
$R P M$ & $:$ & 2400 \\
$L$ & $:$ & $1126 \mathrm{~mm}$ \\
$W$ & $:$ & $650 \mathrm{~mm}$ \\
$H$ & $:$ & $778,5 \mathrm{~mm}$ \\
Dry Weight & $:$ & $418 \mathrm{~mm}$ \\
$\eta$ Solar & $:$ & $0,832 \mathrm{ton} / \mathrm{m}^{3}$ \\
Konsumsi Fuel Oil & $:$ & $18 \mathrm{~L} / \mathrm{h}$ \\
& $:$ & $0,018 \mathrm{~m}^{3} / \mathrm{h}$ \\
\hline
\end{tabular}

(Hasil Olahan, 2019)

Tabel 5. Spesifikasi Mesin bantu/genset

\begin{tabular}{lll}
\hline Variabel & & Harga dan Satuan \\
\hline Model & $:$ & $3054 \mathrm{~B}$ \\
Daya & $:$ & $32 \mathrm{~kW}$ \\
& $:$ & $43,5 \mathrm{HP}$ \\
$R P M$ & $:$ & 1500 \\
$L$ & $:$ & $1400 \mathrm{~mm}$ \\
$W$ & $:$ & $735 \mathrm{~mm}$ \\
$H$ & $:$ & $1186 \mathrm{~mm}$ \\
Dry Weight & $:$ & $715 \mathrm{~mm}$ \\
$\eta$ Solar & $:$ & $0,832 \mathrm{ton} / \mathrm{m}^{3}$ \\
Konsumsi Fuel Oil & $:$ & $18 \mathrm{~L} / \mathrm{h}$ \\
& $:$ & $0,018 \mathrm{~m}^{3} / \mathrm{h}$ \\
\hline
\end{tabular}

(Hasil Olahan, 2019)

Spesifikasi mesin induk pada Tabel 3 menunjukkan daya $86 \mathrm{Hp} /$ engine. Karena kapal direncanakan memiliki 2 mesin induk, maka mesin yang dipilih bisa menghasilkan daya total sebesar $172 \mathrm{Hp}$, jauh diatas nilai daya perhitungan pada kapal rancangan yakni 108,312 Hp, sehingga mesin tersebut dianggap cocok untuk digunakan.

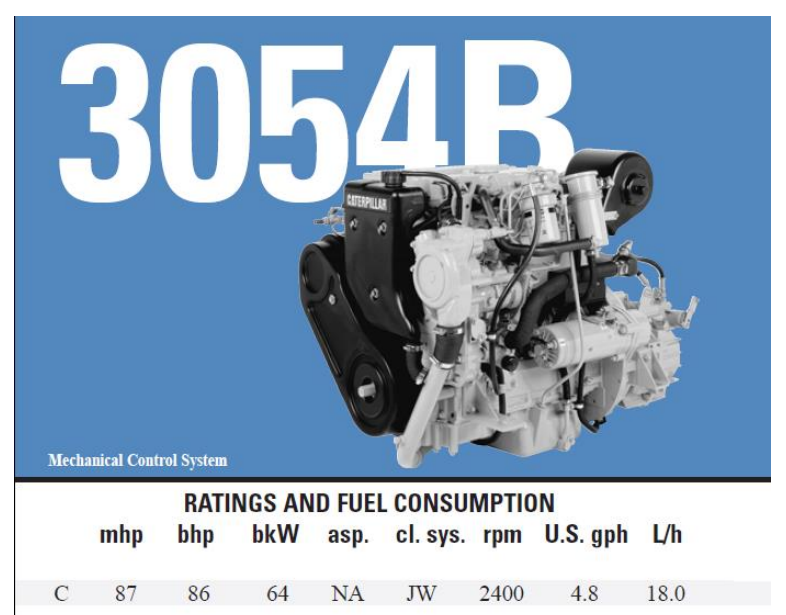

Gambar 7. Mesin Induk Kapal

Untuk genset yang dipilih pada Tabel 4 dengan daya 43,5 Hp/engine, bisa menghasilkan daya total sebesar $87 \mathrm{Hp}$, jauh di atas dari nilai perencanaan mesin bantu/genset kapal rancangan, sehingga 
kebutuhan daya sangat terpenuhi. Detail dari mesin induk dan genset seperti terlihat pada Gambar 7 dan 8.

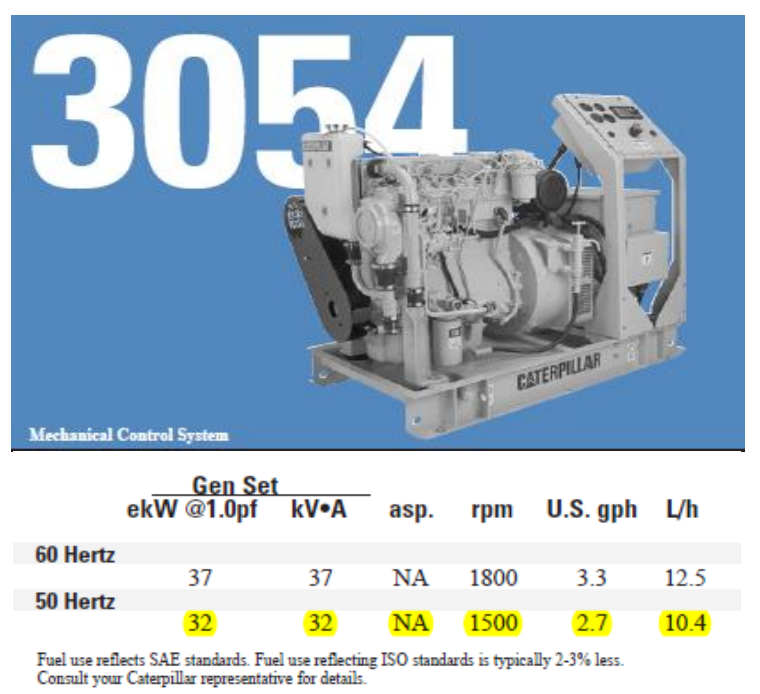

Gambar 8. Mesin Bantu/Genset Kapal

\section{Rencana Umum Kapal}

Sebelum mengerjakan rencana umum, terlebih dahulu dibuat lines plan yang didapatkan dengan menggunakan maxurf kemudian di export dalam format autocad. Gambar lines plan kapal yang terdiri dari body plan, profil plan dan view plan kemudian dicross-chek untuk disempurnakan lagi karena banyaknya garis yang tidak streamline dan saling tumpang tindih. Berikut lines plan kapal seperti terlihat pada Gambar 8 sebagai berikut :

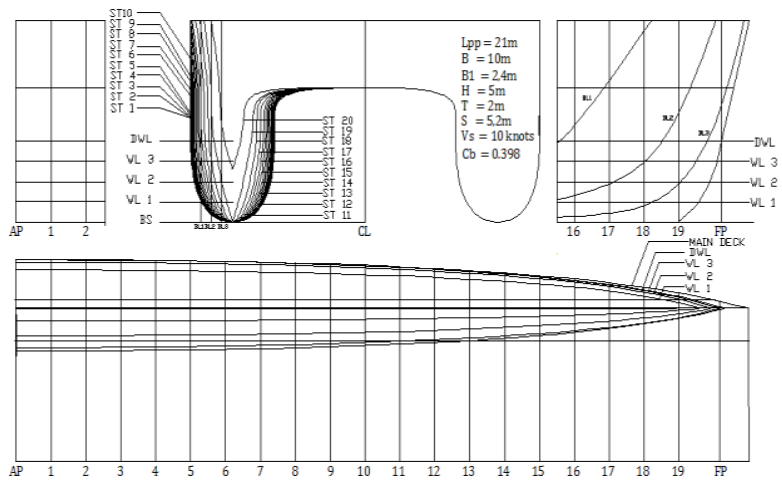

Gambar 9. Lines Plan Kapal

Pada tahapan pembuatan rencana umum kapal ditentukan jumlah penumpang kapal beserta anak buah kapal. Pertimbangan yang digunakan yakni dengan melihat ukuran utama kapal dan kapal pembanding dari sampel yang dijadikan acuan. Mulai dari tinggi bangunan atas, lay out kursi penumpang dan anak buah kapal serta ukuran dari dimensi kursi tersebut. Di rencana umum juga ditentukan harga DWT dan LWT kapal. Bagian DWT kapal meliputi berat dari jumlah penumpang dan kru, barang bawaannya, bahan bakar, minyak lumas, dan air tawar. Estimasi berat DWT kapal, lebih detail dapat dilihat pada Tabel 6 sebagai berikut.
Tabel 6. Estimasi Berat DWT kapal DEAD WEIGHT

\begin{tabular}{lll}
\hline Estimasi Jenis Berat & Jumlah & Satuan \\
\hline Berat Bahan Bakar & 0,351 & ton \\
Berat Minyak Lumas & 0,006 & ton \\
Berat Air Tawar & 2,364 & ton \\
$\begin{array}{l}\text { Berat Penumpang dan Barang } \\
\text { Bawaan }\end{array}$ & 6,8 & ton \\
Berat Kru dan Barang Bawaan & 0,595 & ton \\
SUBTOTAL & $\mathbf{1 0 , 1 1 5}$ & ton \\
\hline
\end{tabular}

(Hasil Olahan, 2019)

Tabel 6 menunjukkan total estimasi DWT kapal rancangan sebesar 10,115 ton. Estimasi berat disesuaikan dengan kecepatan kapal yang direncanakan yakni 10 knot, rute pelayaran sejauh 134,989 nautika mil $( \pm 250 \mathrm{~km})$, dan jumlah penumpang 80 orang beserta kru kapal sebanyak 7 orang.

Bagian LWT merupakan berat kapal kosong yang terdiri dari berat aluminium, berat permesinan, dan berat perlengkapan kapal. Perhitungan berat aluminium dilakukan dengan perkalian tebal pelat dan luasan baik dari software Maxsurf Modeler Advance ataupun Cad. Perhitungan berat permesinan didapatkan dari brosur mesin yang telah dipilih. Sedangkan untuk perhitungan berat perlengkapan didapatkan dengan memastikan berat komponen-komponen terkait dan digabungkan. Kapal Glass Bottom Catamaran Boat ini direncanakan menggunakan material alumunium sebagai bahan dasar konstruksinya. Perhitungan tebal pelat aluminium mengacu pada Lloyd's Register [7]. Aturan tersebut digunakan untuk kapal kayu, kapal dengan material komposit, kapal pesiar dan kapal multihull berukuran kurang dari 24 meter. Penentuan tebal pelat berdasarkan beban. Secara umum perhitungan tebal pelat bisa ditentukan dari persamaan:

$t_{p}=22.4 s \gamma \beta \sqrt{\frac{p_{B P}}{f_{\sigma} 230}} \times 10^{-3}$

Dimana

$t_{p}=$ plate thickness ( $\left.\mathrm{mm}\right)$

$f_{\sigma}=$ Limitting stress coefficient for local loading

$s=$ jarak gading (mm)

$\gamma=$ convex curvature correction factor

$\beta=$ panel aspect ratio correction factor

$p_{B P}=$ design pressure, in $\mathrm{kN} / \mathrm{m} 2$

$=H f . S f$. . $s|H f . S f . P d h| H f . S f . G f . P f$

$H f=$ Hull notation (1.05)

$S f$ = service type factor notation

$G f=$ service area restriction notation factor (0.85)

Ps = shell envelope pressure

Pdh = impact pressure

Pf $=$ Forebody impact pressure 
Setelah dilakukan perhitungan, maka didapatkan tebal pelat masing-masing konstruksi yang dapat dilihat pada Tabel 7 sebagai berikut.

Tabel 7. Tebal Pelat Konstruksi

\begin{tabular}{lll}
\hline Item konstruksi & Tebal & Satuan \\
\hline 1. Pelat Alas & 8 & $\mathrm{~mm}$ \\
2. Pelat Alas Dalam & 8 & $\mathrm{~mm}$ \\
3. Pelat Sisi Main Deck & 8 & $\mathrm{~mm}$ \\
4. Pelat Geladak Cuaca & 8 & $\mathrm{~mm}$ \\
5. Pelat Geladak Interior & 8 & $\mathrm{~mm}$ \\
6. Pelat Sisi Deck House I dan II & 8 & $\mathrm{~mm}$ \\
7. Pelat Dinding Depan Deck House I & 8 & $\mathrm{~mm}$ \\
dan II & & \\
$\begin{array}{l}\text { House I dan II } \\
\text { 9. Bulwark }\end{array}$ & 6 & $\mathrm{~mm}$ \\
10. Jendela Akrilik Demihull & 6 & $\mathrm{~mm}$ \\
11. Jendela Akrilik Geladak & 8 & $\mathrm{~mm}$ \\
\hline Hasil Olahan, 2019) & 8 & $\mathrm{~mm}$ \\
\hline
\end{tabular}

(Hasil Olahan, 2019)

Tebal kaca akrilik yang dipasang di geladak sama dengan tebal pelat geladak, yaitu $6 \mathrm{~mm}$. Sedangankan, tebal kaca yang dipasang di demihull sama dengan tebal pelat lambung, yaitu $8 \mathrm{~mm}$. Berat konstruksi aluminium kapal dapat ditentukan dengan menggunakan persamaan sebagai berikut :

$W_{\text {aluminium }}=A x t \times \eta_{\text {aluminium }}$

dimana

$W_{\text {aluminium }}=$ Berat aluminium $(\mathrm{kg})$

$t \quad=$ Tebal pelat konstruksi $(\mathrm{mm})$

$A=$ Luasan bidang konstruksi $\left(\mathrm{m}^{2}\right)$

$\eta_{\text {Aluminium }}=$ Berat jenis material $\left(2700 \mathrm{~kg} / \mathrm{m}^{3}\right)$

Untuk hasil perhitungan masing-masing berat konstruksi pelat kapal, dapat dilihat pada Tabel 8.

Tabel 8. Berat Konstruksi Pelat Kapal

\begin{tabular}{clll}
\hline No. & $\begin{array}{l}\text { Jenis Konstruksi } \\
\text { Pelat }\end{array}$ & Jumlah & Satuan \\
\hline 1 & Alas & 1,862 & ton \\
2 & Lambung & 6,165 & ton \\
3 & Geladak & 4,00 & ton \\
4 & Bangunan Atas & 3,238 & ton \\
5 & Estimasi Konstruksi & 4,102 & ton \\
6 & Kapal & 1,694 & ton \\
& Sulwark dan Railing & $\mathbf{2 1 , 0 6}$ & ton \\
\hline
\end{tabular}

(hasil olahan, 2019)

Total berat konstruksi pelat kapal sebesar 21,06 ton. Sedangkan akumulasi berat LWT tersaji pada Tabel 9 sebagai berikut:
Tabel 9. Berat Total $L W T$ LIGHT WEIGHT

\begin{tabular}{|c|c|c|c|}
\hline No. & Macam-Macam Berat & Jumlah & Satuan \\
\hline \multicolumn{4}{|c|}{ Permesinan; } \\
\hline 1 & Mesin Induk & 0,836 & ton \\
\hline 2 & Generator & 1,43 & ton \\
\hline \multicolumn{4}{|c|}{ Equipment; } \\
\hline 1 & Kursi Penumpang & 0,76 & ton \\
\hline 2 & Jangkar & 0,12 & ton \\
\hline 3 & Pintu Kabin & 0,033 & ton \\
\hline 4 & Pintu Kedap & 0,14 & ton \\
\hline 5 & Jendela & 0,132 & ton \\
\hline 6 & Peralatan Navigasi & 0,1 & ton \\
\hline 7 & Lifejacket & 0,131 & ton \\
\hline 8 & Lifebuoy & 0,02 & ton \\
\hline 9 & Liferaft & 0,86 & ton \\
\hline \multicolumn{4}{|c|}{ Konstruksi ; } \\
\hline 1 & Alas & 1,862 & ton \\
\hline 2 & Lambung & 6,165 & ton \\
\hline 3 & Geladak & 4,102 & ton \\
\hline 4 & Bangunan Atas & 3,238 & ton \\
\hline 5 & Estimasi Konstruksi Kapal & 4,102 & ton \\
\hline \multirow[t]{2}{*}{6} & Bulwark dan Railing & 1,694 & ton \\
\hline & SUBTOTAL & 25,54 & ton \\
\hline
\end{tabular}

(hasil olahan, 2019)

Pada Tabel 9 didapatkan nilai total berat $L W T$ sebesar 25,54 ton. Nilai akumulasi $L W T+D W T$ diketahui 35,657 ton, selanjutnya dilakukan perhitungan koreksi displasemen yang mengacu pada Hukum Archimedes. Koreksi displasemen adalah selisih antara berat $L W T+D W T$ dengan displasemen awal kapal rancangan. Toleransi yang ditetapkan yakni margin maksimum adalah $\pm 5 \%$. Pengecekan koreksi displasemen kapal seperti terlihat pada Tabel 10 sebagai berikut :

Tabel 10. Koreksi displasemen kapal

Koreksi Displasemen Menurut Hukum Archimedes

Displ. Berat (penjabaran berat $L W T$

$+D W T$ )

35,657 ton

Displasemen awal rancangan

34 ton

Selisih margin $\pm 5 \%$ dari displasemen rancangan

Selisih maksimal yang diijinkan $\quad \pm 1,700$ ton

Selisih displasemen dan displ. berat $-1,657$ ton total

$-4,875 \%$

Kesimpulan

Accepted

(Hasil Olahan, 2019)

Hasil koreksi displasemen berdasarkan hukum archimedes pada Tabel 10 menunjukkan accepted/memenuhi karena selisih antara displasemen berat $(L W T+D W T)$ dan displasemen awal kapal rancangan tidak melibihi 5\%

Setelah dilakukan koreksi displasemen kemudian dilakukan penataan ruang di atas kapal berdasarkan pertimbangan jumlah penumpang kapal beserta anak buah kapal. Gambar tata letak 
ruang kapal seperti terlihat pada Gambar 10 sebagai berikut :

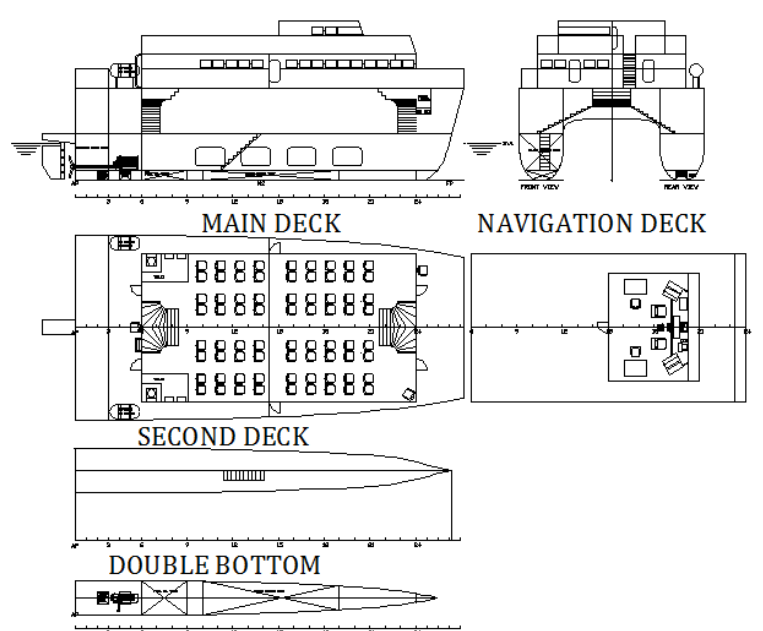

Gambar 10. Tata Letak Ruang di Kapal

Setelah penataan ruang dilakukan, didapatkan jumlah penumpang maximum yakni 80 orang dan anak buah kapal 7 orang. Daya tampung keseluruhan kapal sebanyak 87 orang. Tinggi bangunan atas yakni 2,2 meter, tinggi second deck 2,5 meter sementara dimensi kursi yakni $\mathrm{B}_{\text {kursi }}=$ 0,45 meter, $\mathrm{L}_{\text {kursi }}=0,45$ meter, dan $\mathrm{H}_{\text {kursi }}=1,06$ meter. Ruangan-ruangan yang tersedia yakni ruang penumpang, ruang navigasi, ruang mesin, toilet, steering gear room, chain locker, mud box, dan glass bottom room. Untuk perencanaan tangki-tangki dikapal terdapat lubricant tank, sludge tank, fuel oil tank, fresh water tank, dan ballast tank.

\section{KESIMPULAN}

Dari hasil penelitian ini diperoleh sebuah dimensi kapal dan spesifikasi teknis lainnya yang cocok dioperasikan di kepulauan Derawan yakni kapal dengan lambung katamaran sebagai moda transportasi pariwisata berupa waterbus dengan tipe glass bottom. Berikut adalah ukuran utama dan spesifikasinya :

$\begin{array}{llll}L & = & 21 & \mathrm{~m} \\ T & = & 2 & \mathrm{~m} \\ B 1 & = & 2,4 & \mathrm{~m} \\ S & = & 5,2 & \mathrm{~m} \\ H & = & 5 & \mathrm{~m} \\ B & = & 10 & \mathrm{~m} \\ C b & = & 0,33 & \\ B H P & = & 108,312 \mathrm{Hp}\end{array}$

Engine Type $=3054 \mathrm{~B}$, Cartepillar marine $\mathrm{V} \quad=\quad 10 \mathrm{knot}$

Kapasitas penumpang = 80 orang

Jumlah ABK = 7 orang

Tinggi bangunan atas $=2,2$ meter.

Tinggi Second deck = 2,5 meter

Tebal kaca akrilik di geladak sama $\quad=6 \mathrm{~mm}$.

Tebal kaca akrilik di demihull $\quad=8 \mathrm{~mm}$.

\section{UCAPAN TERIMA KASIH}

Ungkapan terimakasih kepada Dinas Pariwisata Pemkab. Berau, Ditjen Perhubungan Laut Provinsi Kalimantan Timur, dan Program Studi Teknik Perkapalan Institut Teknologi Kalimantan yang telah membeli license academic version software Maxurf 212019 sehingga makalah ini bisa dipublikasikan.

\section{REFERENSI}

[1] CAT, "Marine Power Solution Engines and Generator sets Catalog" 2018.

[2] Dinas Kebudayaan dan Pariwisata Berau, "Kunjungan Objek Wisata Berau Didominasi Wisman" 2017. [online] Available : "http://disbudpar.bberaukab.go.id/kunjungan -objrk-wisata-berau-didominasiwiswan/[diakses pada 9 februari 2019].

[3] International Maritime Organization, "Aexplanatory Notes To The International Code On Intact Stability Chapter 3 - Part. A," 2008.

[4] Insel, M. dan Molland, A. F. "An Investigation Into The Resistance Components of High Speed Displacement Catamarans. London: The Royal Institution of Naval Architects, 1991.

[5] Kaltim Tribun News, "Pemkab Berau Targetkan Pendapatan 3 Trilyun, 2017. [online]. Available:

http://kaltim.tribunnews.com/2017/08/06/p emkab-berau-targetkan-pendapatan-rp 3triliun-dari-wisata-selam [diakses pada 9 Februari, 2019]

[6] Lewis E. V., "Principle of Naval Architecture Vol. II, Resistance, Propulsion and Vibration The Society of Naval Architects and Marine Engineers, 601 Pavonia Avenue Jersey City, NJ, 1988.

[7] Lloyd's Register. Rules and Regulations for The Classification of Special Craft Service, Part 7 Hull construction in Aluminium, 2016.

[8] Parsons, Michael G., "Ship Design and Construction Volume II". Jersey City : The Society of Naval Architect and Marine Engineering, 2003.

[9] Sahoo, Salas, \& Schwetz, Practical evaluation of resistance of high-speed catamaran hull forms-Part I, 2007.

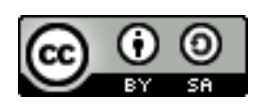

This is an open access article which means that all content is freely available without charge to the user or his/her institution. Jurnal Saintis allows the author(s) to hold the copyright without restriction. The copyright in the text of individual rticles (including research article, opinion articles, and abstracts) is the property of their respective authors distriuted under the terms of the Creative Commons Attribution-ShareAlike 4.0 International 
License (http://creativecommons.org/licenses/bysa/4.0/) which permits unrestricted use, distribution, and reproduction in any medium. Users are allowed to read, download, copy, distribute, search, or link to full-text articles in this journal without asking by giving appropriate credit, provide a link to the license, and indicate if changes were made. 